\title{
Growth and Morphological Characterisation of Tropical Thermophilic Bacterium Parageobacillus caldoxylosilyticus ER4B
}

\author{
XIN JIE CHING ${ }^{1}$, NAZALAN NAJIMUDDIN $^{2}$, YOKE KQUEEN CHEAH ${ }^{3}, \&$ CLEMENTE $^{2}$ \\ MICHAEL VUI LING WONG ${ }^{1,4 *}$
}

${ }^{1}$ Biotechnology Research Institute, Universiti Malaysia Sabah, 88400 Kota Kinabalu, Sabah, Malaysia; ${ }^{2}$ School of Biological Science, Universiti Sains Malaysia, Persiaran Bukit Jambul 11900 Bayan Lepas, Penang, Malaysia; ${ }^{3}$ Department of Biomedical Science, Faculty of Medicine and Health Sciences, Universiti Putra Malaysia, 43400 UPM Serdang, Selangor Darul Ehsan, Malaysia; ${ }^{4}$ National Antarctic Research Centre, University of Malaya, 50603 Kuala Lumpur, Malaysia Corresponding author: michaelw@ums.edu.my Received: 14 October $2021 \quad$ Accepted: 12 December 2021 Published: 31 December 2021

\begin{abstract}
Parageobacillus caldoxylosilyticus is a rod-shaped thermophilic bacterium that can grow optimally at high temperatures. The thermophilic features of the bacterium are expected to be largely accounted by the production of thermostable enzymes which has valuable applications in many fields. However, growth study on this species is very limited and the growth conditions at high temperatures remained unclear. Therefore, this study aimed to determine the morphological and growth characterisation of Parageobacillus caldoxylosilyticus, including growth media preferences, optimal growth temperature, and construction of growth curve. P. caldoxylosilyticus strain ER4B that was isolated from oil palm empty fruit bunch compost was characterised in this study. The bacterial strain was firstly identified based on 16S rRNA gene sequence, and the subsequent sequence similarity search showed that it is closest to P. caldoxylosilyticus strain UTM6. It is found that ER4B grew best in Lennox Broth as compared to Reasoner's 2A Broth, Trypticase Soy Broth, and Nutrient Broth media. Further tests were conducted and the optimum growth temperature of the strain was determined to be at $64{ }^{\circ} \mathrm{C}$. The bacterium forms mucoid circular punctiform colonies that are yellowish and with diameter of $2 \mathrm{~mm}$ to $4 \mathrm{~mm}$. It is a Gram-positive rod-shaped bacterium that has a length ranging from $3 \mu \mathrm{m}$ to $6 \mu \mathrm{m}$, with a diameter of around $0.5 \mu \mathrm{m}$.
\end{abstract}

Keywords: 16S ribosomal RNA, characterisation, fruit bunch compost, Parageobacillus caldoxylosilyticus, thermophilic bacteria

Copyright: This is an open access article distributed under the terms of the CC-BY-NC-SA (Creative Commons Attribution-NonCommercial-ShareAlike 4.0 International License) which permits unrestricted use, distribution, and reproduction in any medium, for non-commercial purposes, provided the original work of the author(s) is properly cited.

\section{INTRODUCTION}

Parageobacillus sp. were previously categorised together with other Geobacillus sp., the new genus, Parageobacillus was then proposed by Aliyu et al. (2016) as high-resolution phylogenomic analysis showed two distinct clustering among sixty-three Geobacillus stains, and the difference is significant to separate Parageobacillus from Geobacillus (Aliyu et al., 2016; Lebre et al., 2018). To date there are seven known species being classified into this genus, namely $P$. caldoxylosilyticus, $P$. galactosidasius., $P . \quad$ thermantarcticus., $P$. thermoglucosidasiusi, $P$. toebii, $P$. yumthangensis, and $P$. genomosp. 1 (Schoch et al., 2020). Members of Parageobacillus are characterised by their rod-shaped morphology, presence of Gram-positive cell wall, and most importantly, their thermophilic properties (Nazina et al., 2001). Bacterial species from this genus can grow optimally at a temperature ranging from $45^{\circ} \mathrm{C}$ to $75{ }^{\circ} \mathrm{C}$, while some can extend to as low as $35{ }^{\circ} \mathrm{C}$ or as high as $80{ }^{\circ} \mathrm{C}$ (Zeigler, 2014). Thermophiles such as Parageobacillus are expected to produce thermostable hydrolytic enzymes that are able to function at higher temperatures.

Parageobacillus caldoxylosilyticus was first isolated and identified as Saccharococcus caldoxylosilyticus from local soil in Melbourne, Australia (Ahmad et al., 2000), before it was classified as Geobacillus caldoxylosilyticus in 2001 (Fortina et al., 2001) and lastly classified as Parageobacillus caldoxylosilyticus in 2016 
(Aliyu et al., 2016). This species was found not only in soil (Ahmad et al., 2000), chipped woody waste (Yunitsyna et al., 2019), oilcontaminated soil (Adlan et al., 2020), volcanic soil (Seo et al., 2011), but it was also found in a liquid such as seawater (Adlan et al., 2020), pond water (Abdelkader \& Esawy, 2011), hot spring (Ibrahim \& Ahmad, 2017; Kolcuoğlu et al., 2010), central heating system water (Obojska et al., 2002), and in the dairy product (Berendsen et al., 2016). Besides, the species also showed high adaptability towards various environmental stress other than temperature, as it was able to tolerate glyphosate, heavy metal toxicity, oil contamination, as well as high salinity and alkalinity (Obojska et al., 2002; Abdelkader \& Esawy, 2011; Ibrahim \& Ahmad, 2017; Yunitsyna et al., 2019; Adlan et al., 2020). These unique properties of $P$. caldoxylosilyticus made this species a promising candidate for the production of industrially applicable thermostable enzymes such as xylanase, maltogenic amylase, and acylhomoserine lactonase, at the same time, offer an environmentally friendly solution of herbicide degradation, bioremediation of harmful chromium IV oxide, and crude oil paraffin wax degradation (Obojska et al., 2002; Kolcuoğlu et al., 2010; Abdelkader \& Esawy, 2011; Seo et al., 2011; Rahim \& Ahmad, 2016; Ibrahim \& Ahmad, 2017; Yunitsyna et al., 2019; Adlan et al., 2020).

Despite having applicable potential in various fields, similar to the majority of Parageobacillus members, studies on growth characterisation and cell morphology of $P$. caldoxylosilyticus are relatively less. In addition, the growth conditions appeared to be different for different strains (Ibrahim \& Ahmad, 2017; Ahmad et al., 2000). Without information on the optimal growth conditions it is very difficult to utilize the bacteria for downstream application (Allen \& Waclaw, 2019). Therefore, this study aimed to determine the optimal growth conditions of $P$. caldoxylosilyticus ER4B which was isolated from Malaysia oil palm empty fruit bunch compost. Since this is the very first study attempt on strain ER4B, the bacterium was first identified using the 16S rRNA gene sequencing and alignment prior to the any other growth characterisation. Microscopic analysis was also conducted in this study to examine the cell morphology of strain ER4B.

\section{MATERIALS AND METHODS}

\section{Source of Bacterium}

Parageobacillus caldoxylosilyticus strain ER4B used for this study was previously isolated from oil palm empty fruit bunch during the composting process on 11 th November 2005. It was stored in glycerol stock at $-80{ }^{\circ} \mathrm{C}$, and was recovered for the purpose of this study.

\section{Bacterial Identification}

Bacterial DNA of ER4B was isolated using an optimized protocol using Qiagen DNeasy ${ }^{\circledR}$ Blood \& Tissue Kit, followed by PCR amplification of the complete 16S rRNA gene using forward primer BSF8 (5, AGAGTTTGATCCTGGCTCAG - 3') and reverse primer BSR1541 (5' AAGGAGGTGATCCAGCCGCA - 3'). The 16S rRNA gene was used for identification because it is by far the most common housekeeping genetic marker, and the nearly complete 16S rRNA 1.5 KB fragment sequence has been reported to allow identification up to species level (Cai et al., 2003; Janda \& Abbott, 2007; Johnson et al., 2019; Jeong et al., 2021). The amplicon size was expected to be approximately 1,500 bp. The subsequent purified 16S amplicon was then sequenced using the ABI3730XL Sanger sequencer, and the sequence was searched for similarities against NCBI databases using the Basic Local Alignment Search Tool (BLAST). A phylogenetic tree was constructed based on the 16S rRNA sequences of bacteria using Mega X. The tree was inferred using the Maximum Composite Likelihood based on 1000 resamples data set.

\section{Determination of Optimal Culture Media}

A test was conducted to determine which of the selected culture media would offer the best growth condition for the bacterium. $100 \mathrm{ml}$ of Lennox Broth (LB), Trypticase Soy Broth (TSB), Reasoner's 2A (R2A) Broth, and Nutrient Broth $(\mathrm{NB})$ were prepared in three replicates. Next, $10 \mu \mathrm{l}$ of bacterial culture with $\mathrm{OD}_{600}$ below 0.05 was inoculated into each of the freshly prepared broth media. The initial $\mathrm{OD}_{600}$ of each culture was measured using Spectra Max 2 before they were incubated at $60^{\circ} \mathrm{C}$ and 180 rpm for 24 hours. The $\mathrm{OD}_{600}$ from each replicate 
were taken and recorded after 24 hours. Statistical analysis was performed using One-way Analysis of Variance (ANOVA).

\section{Determination of Optimal Growth Temperature}

The optimal growth temperature was tested after LB was determined to be the most suitable medium among the tested broth media. In order to narrow down the temperature range of ER4B, $1 \mu \mathrm{l}$ of bacteria culture with $\mathrm{OD}_{600}$ below 0.05 , were inoculated onto LB agar plates, followed by incubation at $25^{\circ} \mathrm{C}, 30^{\circ} \mathrm{C}, 40{ }^{\circ} \mathrm{C}, 50{ }^{\circ} \mathrm{C}, 60$ ${ }^{\circ} \mathrm{C}, 70{ }^{\circ} \mathrm{C}$, and $80{ }^{\circ} \mathrm{C}$ for 24 hours. After narrowing down the temperature to $60{ }^{\circ} \mathrm{C}$ and $70^{\circ} \mathrm{C}, 10 \mu \mathrm{l}$ of bacterial culture with $\mathrm{OD}_{600}$ below 0.05 was inoculated into freshly prepared LB broth media, before each triplicate was incubated at $60{ }^{\circ} \mathrm{C}, 62{ }^{\circ} \mathrm{C}, 64{ }^{\circ} \mathrm{C}, 66{ }^{\circ} \mathrm{C}, 68^{\circ} \mathrm{C}$, and $70{ }^{\circ} \mathrm{C}$, at shaking speed of $180 \mathrm{rpm}$ for 24 hours. The $\mathrm{OD}_{600}$ from each replicate were taken and recorded after 24 hours.

\section{Construction of Growth Curve}

The growth curve was constructed using the most suitable broth medium and optimum growth temperature for the bacterium. $10 \mu 1$ of bacterial culture with $\mathrm{OD}_{600}$ below 0.05 was inoculated into $100 \mathrm{ml}$ freshly prepared LB broth media, followed by incubation at $64^{\circ} \mathrm{C}$ and $180 \mathrm{rpm}$. The absorbance of the cultures was measured at an interval of 3 hours, for 39 hours continuously.

\section{Bacterial Cell and Colony Morphology}

The morphology of the bacterial cell and the bacterial colony was assessed using different microscopes. For microscopic analysis of bacterial colony and Gram staining (Hucker \& Conn, 1923), compound light microscope Olympus BX41 was used, whereas the bacterial cell morphology was viewed under Scanning Electron Microscope (SEM) Hitachi S3400N.
Prior to SEM examination, the cells were prepared using a modified Hexamethyldisilazane (HMDS) drying method (Murtey \& Ramasamy, 2016).

\section{RESULTS AND DISCUSSION}

After sequencing and BLAST against the NCBI database, the resulting 16S rRNA sequence suggested that the bacterium has $99 \%$ similarity to Parageobacillus caldoxylosilyticus strain UTM6, with an E-value of 0.0. The majority of the top 100 sequences producing significant alignment from BLAST were all from the species of $P$. caldoxylosilyticus. The neighborjoining phylogenetic tree was constructed based on the 16S rRNA sequence of strain ER4B against some of the sequences selected from these top 100 sequences, including those from the closely related genus. Figure 1 showed that strain ER4B of the bacterium is significantly closer to $P$. caldoxylosilyticus as it formed a distinctive cluster with this species, and it is particularly close to $P$. caldoxylosilyticus strain UTM6, with less than 0.01 (1\%) nucleotide substitution per site. Therefore, strain ER4B is highly likely to be $P$. caldoxylosilyticus. Besides, the phylogenetic relationship depicted in the tree is highly reliable, as all the bootstrap values shown on the nodes are exceptionally high (around 98).

Among the four different broth mediums, the bacterium was cultured in, LB showed the highest average $\mathrm{OD}_{600}$ reading (0.2998) after 24 hours of incubation (Table 1). This indicated LB has significantly highest turbidity due to the highest bacterial growth rate when cultured in this broth medium $(p<0.05)$. So, LB appeared to be the most suitable growth media for ER4B as compared to the rest. Next to LB, it can be clearly seen that $\mathrm{R} 2 \mathrm{~A}$ has an average $\mathrm{OD}_{600}$ reading of 0.1224 , followed by TSB with average $\mathrm{OD}_{600}$ reading of 0.0891 . On the other hand, there was no observable growth in NB at all. 


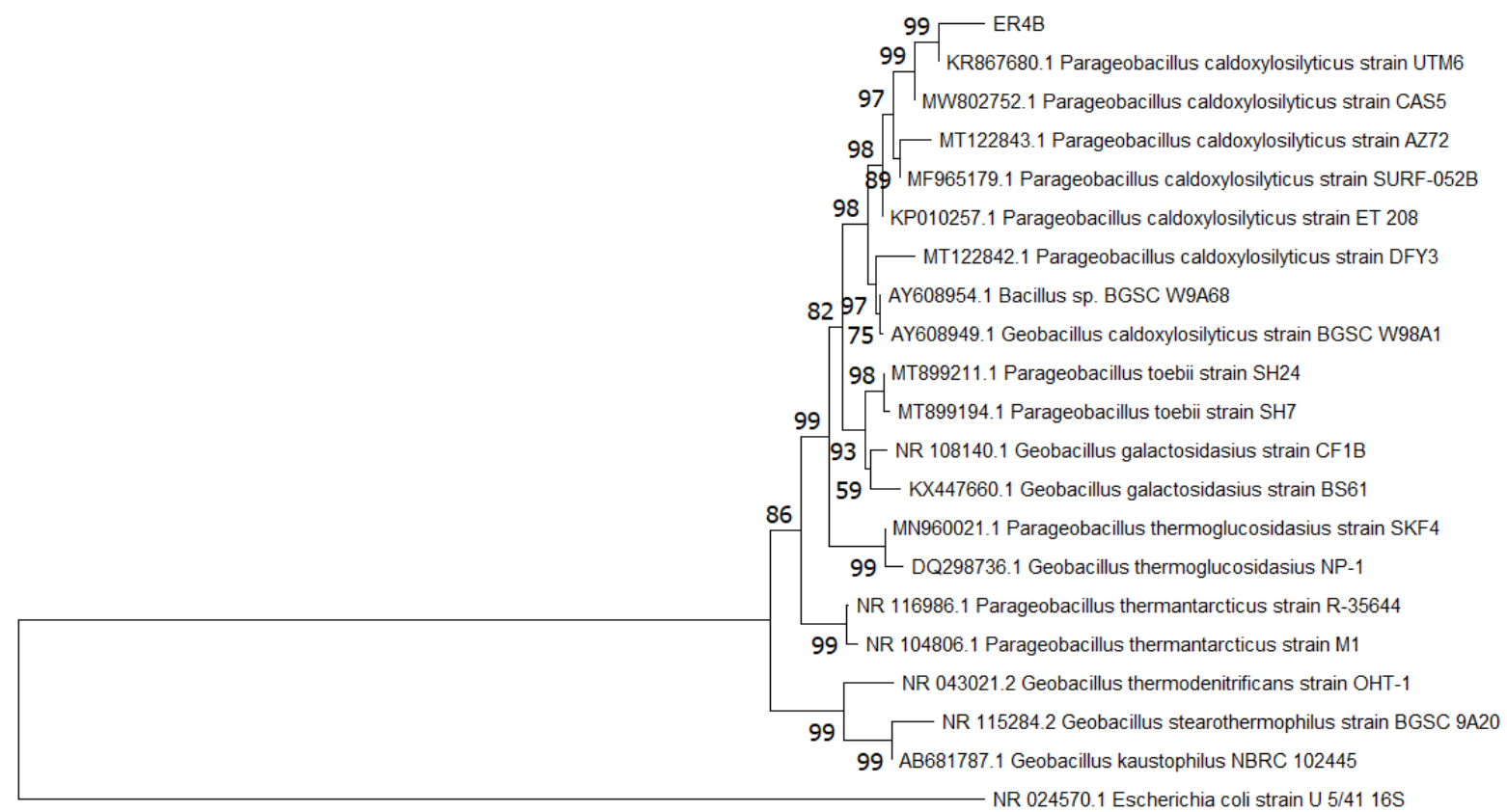

0.020

Figure 1. Phylogenetic tree based on 16S rRNA sequence similarity of ER4B and other bacterial strains selected from the BLASTn significant alignment using MEGA X. The evolutionary history was inferred using NeighborJoining method, whereas the distances were computed using the Maximum Composite Likelihood method, in the units of the number of base substitutions per site. Escherichia coli strain U 5/41 was included as outgroup. Numbers shown at the nodes represent bootstrap percentages based on 1000 resampled dataset

Table 1. Optical density (absorbance at $600 \mathrm{~nm}$ ) at different types of broth culture media after 24 hours of incubation at $60{ }^{\circ} \mathrm{C}$. the p-value corresponding to the F-statistic of one-way ANOVA is lower than 0.05, suggesting that results are significantly different. $[\mathrm{F}(2,6)=97.251$; $\mathrm{p}$-value $=0.00003]$

\section{OD600 readings}

\section{Types of broth media}

$\begin{array}{llll}\text { Replicate } 1 & \text { Replicate } 2 & \text { Replicate } 3 \quad \text { Average }\end{array}$

\begin{tabular}{ccccc}
\hline LB & $\mathbf{0 . 2 9 3 1}$ & $\mathbf{0 . 3 0 0 9}$ & $\mathbf{0 . 3 0 5 5}$ & $\mathbf{0 . 2 9 9 8}$ \\
R2A & 0.1138 & 0.1354 & 0.1181 & 0.1224 \\
TSB & 0.1210 & 0.0890 & 0.0572 & 0.0891 \\
NB & N/A & N/A & N/A & N/A \\
\hline
\end{tabular}

*N/A indicates Not Available.

When the nutrient content of each culture medium is compared, the most distinguishable nutrient content difference between LB and other culture media would be the presence of yeast extract at a relatively high concentration. Yeast extract is commonly added in many culture media as a major source of vitamins, different amino acids, as well as certain trace elements (Hakobyan et al., 2012). It has been shown to serve as the best organic nitrogen source for cell growth and $\mathrm{H} 2$ production by different bacteria, e.g., Clostridium 
acetobutylicum (Kalil et al., 2008) and Rhodopseudomonas palustris (Chen et al., 2010). This suggested that high yeast extract concentration in LB is probably the main growth factor that stimulates the growth of ER $4 B$.

As for growth temperature, no significant growth can be observed at $25{ }^{\circ} \mathrm{C}$ and $80{ }^{\circ} \mathrm{C}$. Table 2 showed that the lowest temperature where growth of ER4B can be observed (minimum growth temperature) was between 25 ${ }^{\circ} \mathrm{C}$ and $30{ }^{\circ} \mathrm{C}$, whereas the highest temperature where growth occur (maximum growth temperature) was in between $70{ }^{\circ} \mathrm{C}$ to $80{ }^{\circ} \mathrm{C}$ (Table 2). Table 2 also showed that the growth of ER4B was very slow at $30{ }^{\circ} \mathrm{C}$ as the colonies formed were very small and transparent, but the colonies appeared to be bigger and thicker, indicating that the growth rate increased along with the temperature increment. The size of the colonies was the biggest at $60{ }^{\circ} \mathrm{C}$, and further increase in temperature to $70{ }^{\circ} \mathrm{C}$ causes the colony size to reduce significantly, so the maximum growth temperature was expected to be just slightly above $70{ }^{\circ} \mathrm{C}$.

Table 2. Growth of strain ER4B on LB agar plate at different temperatures

\begin{tabular}{c} 
Growth on LB agar plate \\
\hline 25 \\
30 \\
Temperature $\left({ }^{\circ} \mathbf{C}\right)$ \\
40 \\
50 \\
60
\end{tabular}

Further temperature tests between $60{ }^{\circ} \mathrm{C}$ to $70{ }^{\circ} \mathrm{C}$ revealed the optimum growth temperature for strain ER4B. Of the temperatures listed in Table 3, bacteria culture at $64{ }^{\circ} \mathrm{C}$ has the highest average $\mathrm{OD}_{600}$ reading of 0.4063 after 24 hours of incubation, followed by $66^{\circ} \mathrm{C}(0.3886), 62{ }^{\circ} \mathrm{C}$ (0.3599), $68{ }^{\circ} \mathrm{C}(0.3110), 60{ }^{\circ} \mathrm{C}(0.3000)$, and lastly $70{ }^{\circ} \mathrm{C}(0.2144)$. Higher $\mathrm{OD}_{600}$ reading is equivalent to higher turbidity or higher bacterial cell density in the culture media, thus, $64{ }^{\circ} \mathrm{C}$ with the highest $\mathrm{OD}_{600}$ reading was showing the highest growth rate as compared to other incubation temperatures. This suggested $64{ }^{\circ} \mathrm{C}$ as the optimal growth temperature for ER4B.

The growth temperatures of Parageobacillus caldoxylosilyticus has been briefly described by Ahmad et al. (2000). The study proposed that the formerly known as Geobacillus caldoxylosilyticus has optimal growth temperature ranges between $65{ }^{\circ} \mathrm{C}$, at the same time having a minimum temperature at $42{ }^{\circ} \mathrm{C}$ 
and maximum temperature at $70{ }^{\circ} \mathrm{C}$ (Ahmad et al., 2000). The reported optimal growth temperature and the maximum temperature are very similar to the temperature obtained in this study, however, the minimum growth temperature of ER4B appeared to be lower than those reported strains. However, it is still consistent with other members of Geobacillus genus (Zeigler, 2014). Another relatively recent growth study on $P$. caldoxylosilyticus UTM6 reported an optimal growth temperature at $55^{\circ} \mathrm{C}$ (Ibrahim \& Ahmad, 2017), and the reported temperature is significantly lower than the optimal growth temperature obtained from this study and Ahmad et al. (2000). Therefore, in terms of growth temperature, the results obtained in this study is in consistent with Ahmad et al. (2000), but appeared to be very different from the optimal growth temperature reported by Ibrahim \& Ahmad (2017).

Table 3. Optical density (absorbance at $600 \mathrm{~nm}$ ) at different temperature in each culture replicate after 24 hours of incubation

\begin{tabular}{ccccc}
\hline \multirow{2}{*}{$\begin{array}{c}\text { Temperature } \\
\left({ }^{\circ} \mathrm{C}\right)\end{array}$} & Replicate 1 & Replicate 2 & Replicate 3 & Average \\
\cline { 2 - 5 } & 0.2978 & 0.2952 & 0.3070 & 0.3000 \\
$\mathbf{6 0}$ & 0.3363 & 0.3700 & 0.3734 & 0.3599 \\
$\mathbf{6 2}$ & $\mathbf{0 . 4 2 0 4}$ & $\mathbf{0 . 3 9 8 1}$ & $\mathbf{0 . 4 0 0 3}$ & $\mathbf{0 . 4 0 6 3}$ \\
$\mathbf{6 4}$ & 0.3909 & 0.3851 & 0.3898 & 0.3886 \\
$\mathbf{6 6}$ & 0.3270 & 0.3055 & 0.3004 & 0.3110 \\
$\mathbf{6 8}$ & 0.2117 & 0.2128 & 0.2186 & 0.2144 \\
\hline $\mathbf{7 0}$ & & & & \\
\hline
\end{tabular}

The growth curve of strain ER4B cultured at optimal growth temperature and broth media was constructed and depicted in Figure 2. For the first three hours, there was no significant rise in absorbance reading. This indicated that the culture was in the lag phase of growth (Walker, 1999). In this case, after ER4B was inoculated into fresh $\mathrm{LB}$, it took around three hours to adjust their metabolic activities so that they can commence active cell division again.

When the bacterial cells had already adapted to the new environment, they would transit from the lag phase and enter the log or exponential phase. As depicted in Figure 2, ER4B entered the acceleration phase and grew at maximum specific growth rate after the 3rd hour. At around the 9th hour, growth decelerated as essential nutrients became scarce, and eventually entered a stationary phase where the specific growth rate decreased significantly from its maximum point. The stationary phase of ER4B at $64{ }^{\circ} \mathrm{C}$ was short and it was expected to be in between 21 st and 27th hour. After that, the graph exhibited a rapid drop in absorbance readings, indicating that ER4B entered the death phase very quickly after a relatively short transition period in the stationary phase (Werner-Washburne et al., 1993).

When the growth curve was compared to that of strain UTM6 (Ibrahim \& Ahmad, 2017), it can be seen that although strain UTM6 was cultured at $55^{\circ} \mathrm{C}$, but the pattern of the growth curve is very similar to that of ER4B. Strain UTM6 entered exponential phase around $4^{\text {th }}$ hour, while the exponential phase of ER4B started after the $3^{\text {rd }}$ hour. Then both strain entered stationary phase at around $21^{\text {st }}$ hour. Despite having their $\mathrm{OD}_{600}$ recorded at different time interval and different optimal growth temperature, the growth curve from this study agreed well with the reported growth curve. It is speculated that the similarities in growth is due to geographical factors, as both strains were isolated in Malaysia. 


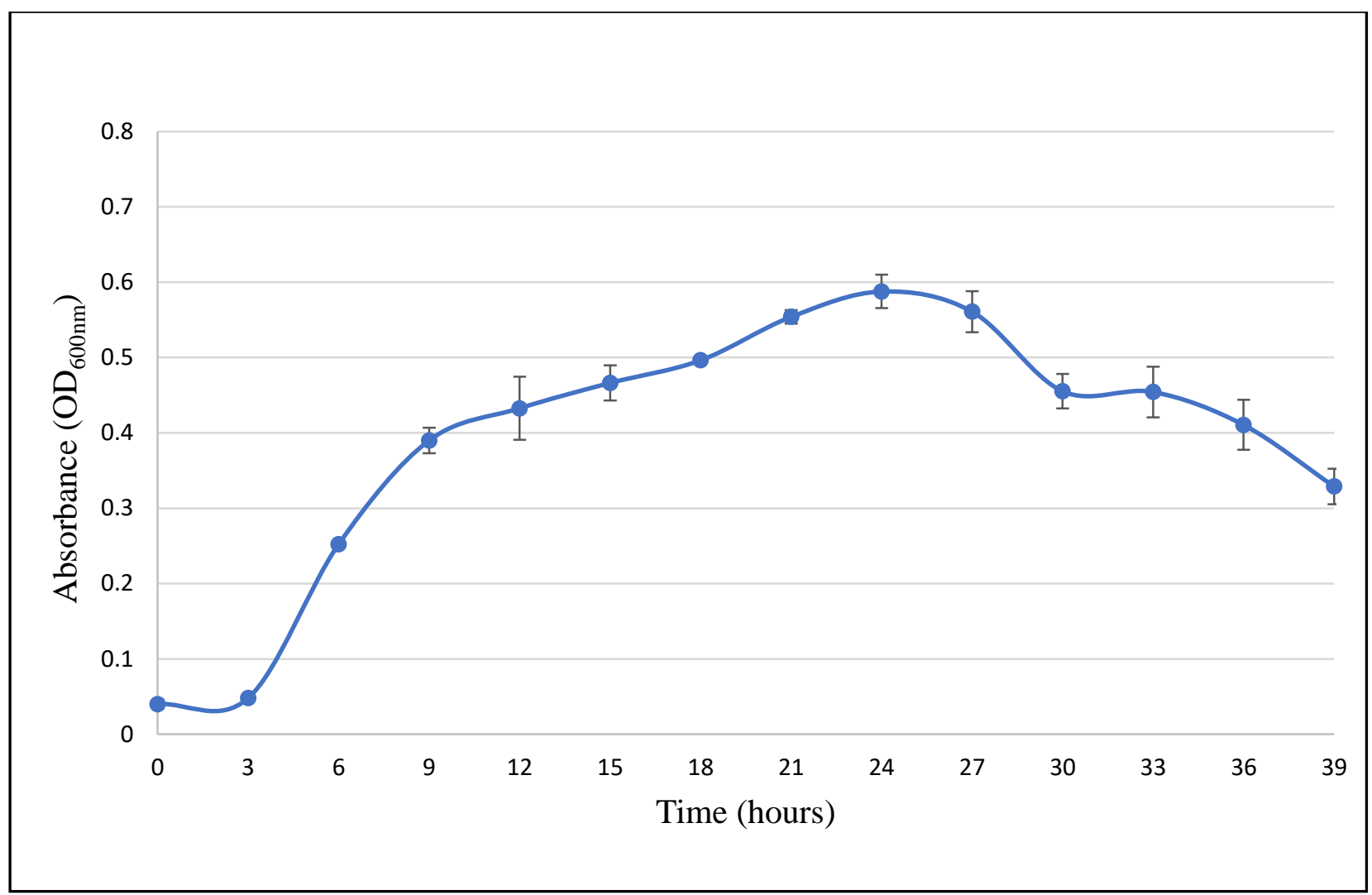

Figure 2. Growth curve of Parageobacillus caldoxylosilyticus strain ER4B cultured in Lennox Broth at $64^{\circ} \mathrm{C}$. The bacterium was in lag phase during the first three hours, immediately followed by exponential phase where the growth rate is maximum. The growth rate then slowed down at $9^{\text {th }}$ hour, and entered stationary phase at $21^{\text {st }}$ hour. After 27 hours of incubation, the absorbance readings were getting lower, indicating the death phase of the bacterial culture

Microscopic observation of ER4B colonies cultured on LB agar plate showed that bacterium strain ER4B formed circular punctiform colony with entire margin as shown in Figure 3. The diameter of average colonies after 24 hours of incubation is about $2 \mathrm{~mm}$ to $4 \mathrm{~mm}$. The colony appeared to be opaque and yellowish-white in color, and it was determined as a mucoid colony as it was sticky and viscous (Mahon et al., 2018). As for elevation (side view), it was flat, while the surface was smooth and shiny. As for Gram staining, the bacterial cells showed violet stain when viewed under the light microscope, suggesting that ER4B has a Gram-positive cell wall (Figure 4).
Further magnification view using a scanning electron microscope (SEM) revealed that strain ER4B has an average length of $3 \mu \mathrm{m}$ to $6 \mu \mathrm{m}$, with a diameter around $0.5 \mu \mathrm{m}$ (Figure 5). Besides, a $\mathrm{Z}$ ring was also observed as depicted in Figures 5(c) and (d). $Z$ ring, also known as Filamenting temperature-sensitive mutant $\mathrm{Z}$ (FtsZ) ring, is a contractile ring assembled in bacterial cells that would proceed to cleave the parent cell into two daughter cells (Lutkenhaus \& Addinall, 1997; Xiao \& Goley, 2016). The position of the $\mathrm{Z}$ ring assembled in the middle of the bacterial cells indicated strain ER4B reproduced through binary fission under normal circumstances. 


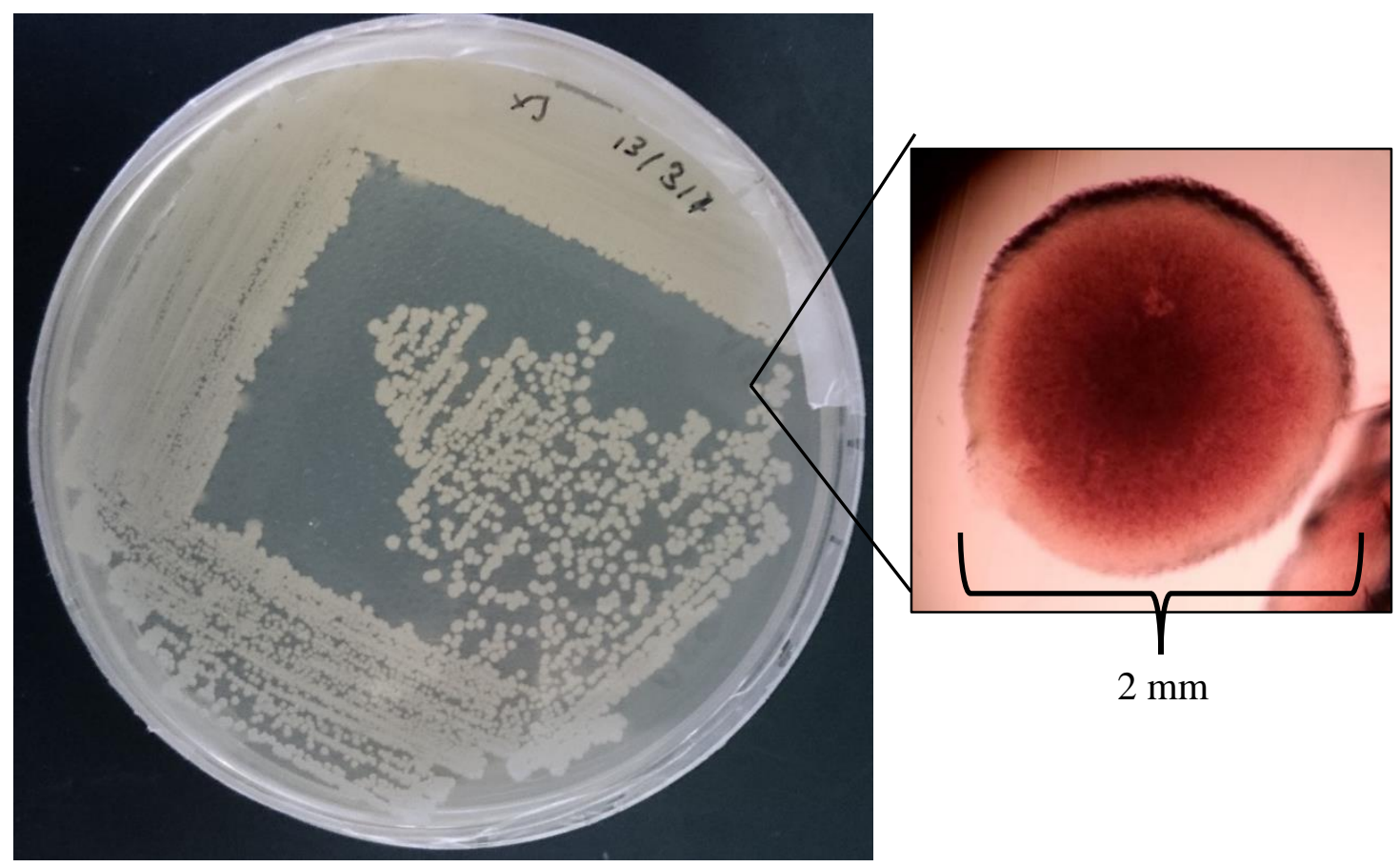

Figure 3. Microscopic view of ER4B single colony for colony morphology characterisation. ER4B forms circular punctiform colony with entire margin that is about $2 \mathrm{~mm}$ to $4 \mathrm{~mm}$ in diameter

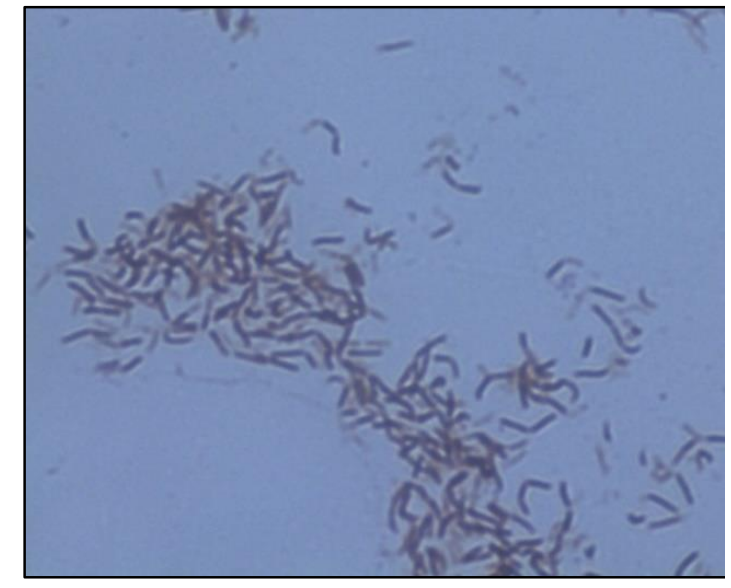

(a)

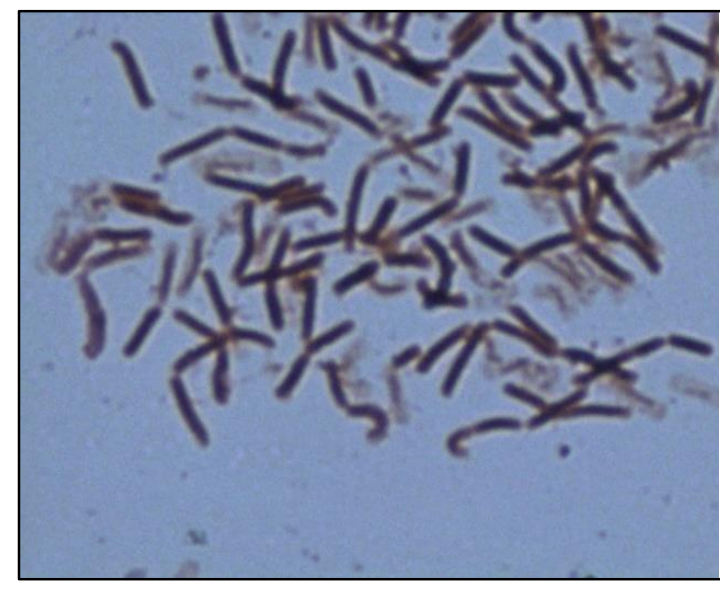

(b)

Figure 4. Microscopic view of Gram-stained ER4B under (a) 400x and (b) 1,000x magnification using light microscope. Violet stains remained in the cell wall of the bacterial cells, suggesting that ER4B is a Gram-positive bacterium. 


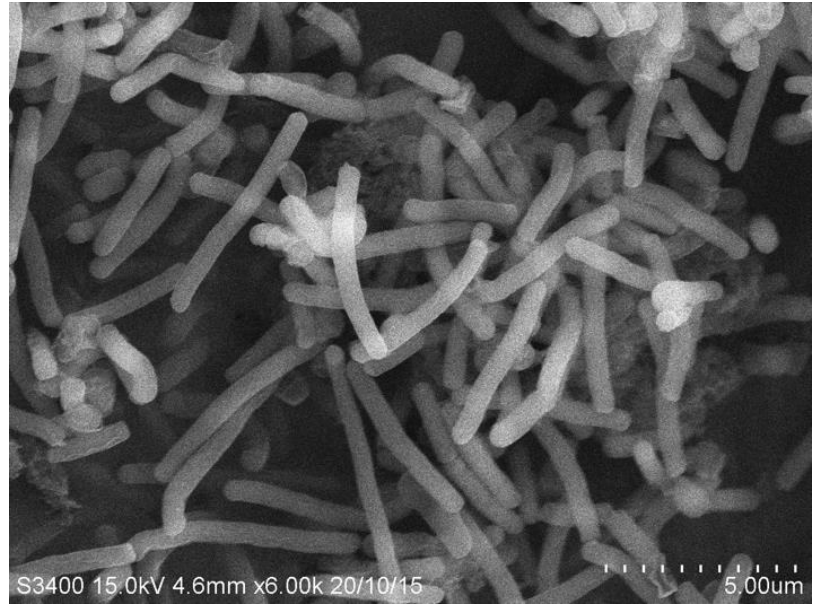

(a)

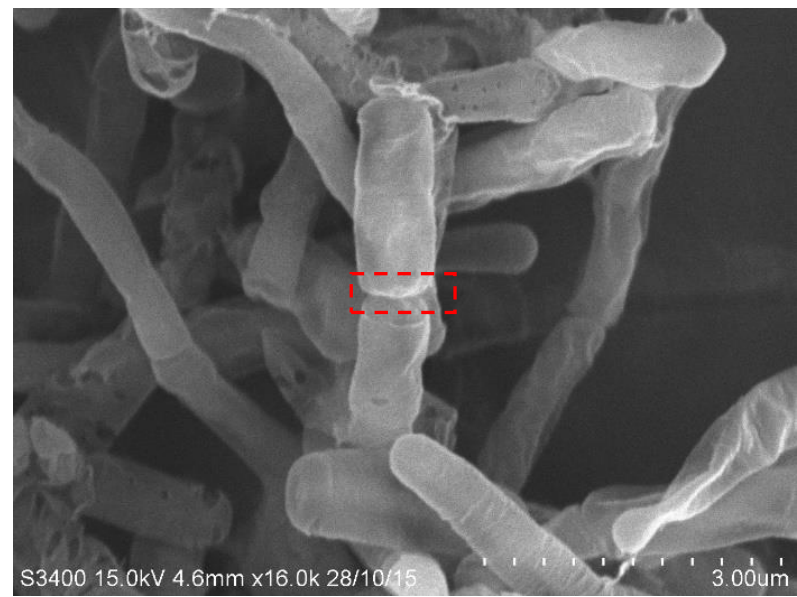

(c)

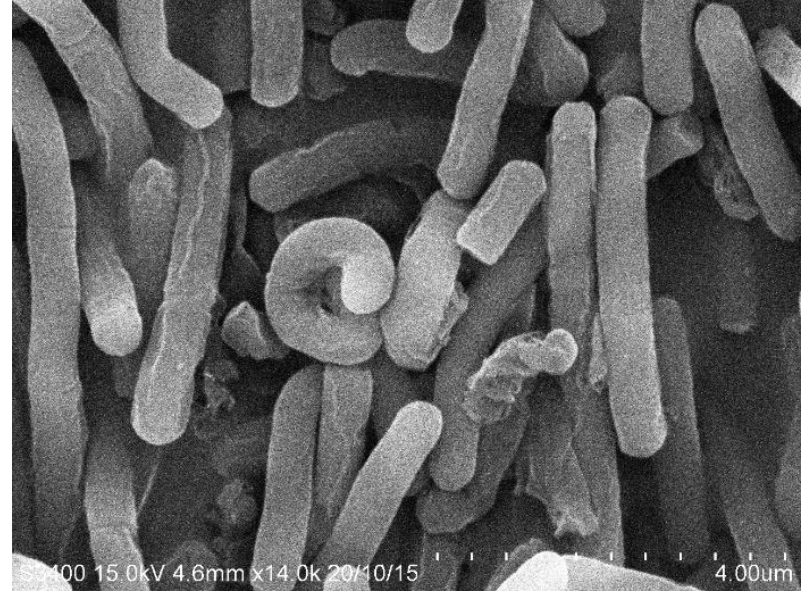

(b)

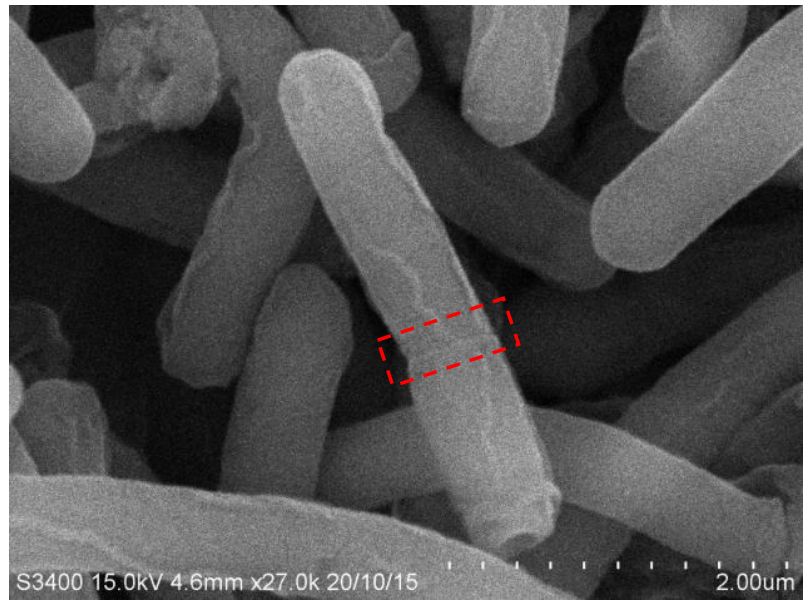

(d)

Figure 5. SEM view of ER4B under different magnification. (a) 6,000x; (b) 14,000x; (c) 16,000x; and (d) 27,000x magnification. $\mathrm{Z}$ ring was observed as highlighted in red

\section{CONCLUSION}

ER4B isolated from tropical oil palm empty fruit bunch compost was preliminarily identified as Parageobacillus caldoxylosilyticus based on the high similarity of its' $16 \mathrm{~S}$ rRNA sequence to $P$. caldoxylosilyticus strain UTM6 (KR867680.1). Growth characterisation showed that the bacterium is a facultative thermophile as it can grow at a temperature as low as $30{ }^{\circ} \mathrm{C}$ while having a maximum growth temperature of 70 ${ }^{\circ} \mathrm{C}$. Besides, strain ER4B has an optimal growth temperature at $64{ }^{\circ} \mathrm{C}$ in $\mathrm{LB}$ media, and the growth curves were also constructed in order to determine the growth pattern. Lastly, strain ER4B was exhibited as a Gram-positive, rodshaped bacterium through microscopic analysis, while forming mucoid circular punctiform colonies which were opaque and yellowishwhite in color when growing on LB agar plate.

\section{ACKNOWLEDGEMENTS}

The funding support from the Ministry of Science, Technology, and Innovation (MOSTI), Malaysia, under the Antarctica Flagship Programme (Sub-Project 1: Grant no. FP1213E036) is gratefully acknowledged.

\section{REFERENCES}

Abdelkader, A.F. \& Esawy, M.A. (2011). Case study of a biological control: Geobacillus caldoxylosilyticus (IRD) contributes to alleviate salt stress in maize (Zea mays L.) plants. Acta Physiologiae Plantarum, 33: 2289. 
Adlan, N.A., Sabri, S., Masomian, M., Ali, M.S.M., \& Rahman, R.N.Z.R.A. (2020). Microbial biodegradation of paraffin wax in Malaysian crude oil mediated by degradative enzymes. Frontiers in Microbiology, 11:565608.

Ahmad, S., Scopes, R.K., Rees, G.N., \& Patel, B.K.C., (2000). Saccharococcus caldoxylosilyticus sp. nov., an obligately thermophilic, xylose-utilizing, endosporeforming bacterium. International Journal of Systematic and Evolutionary Microbiology, 50: 517-523.

Aliyu, H., Lebre, P., Blom, J., Cowan, D., \& De Maayer, P. (2016). Phylogenomic re-assessment of the thermophilic genus Geobacillus. Systematic and Applied Microbiology, 39(8): 527-533.

Allen, R.J. \& Waclaw, B. 2019. Bacterial growth: a statistical physicist's guide. Reports on Progress in Physics. 82(1): 016601.

Berendsen, E.M., Wells-Bennik, M.H.J., Krawczyk, A.O., de Jong, A., van Heel, A., Holsappel, S., Eijlander, R.T., \& Kuipers, O.P. (2016). Draft genome sequences of seven thermophilic sporeforming bacteria isolated from foods that produce highly heat-resistant spores, comprising Geobacillus spp., Caldibacillus debilis, and Anoxybacillus flavithermus. Genome Announcement, 4(3): e00105-e00106.

Cai, H., Archambault, M., \& Prescott, J.F. (2003). $16 \mathrm{~S}$ ribosomal RNA sequence-based identification of veterinary clinical bacteria. Journal of Veterinary Diagnostic Investigation, 15(5): 465-469.

Chen, C.Y., Yeh, K.L., Lo, Y.C., Wang, H.M., \& Chang, J.S. (2010). Engineering strategies for the enhanced photo- $\mathrm{H}_{2}$ production using effluents of dark fermentation processes as substrate. International Journal of Hydrogen Energy, 35(24): 13356-13364.

Fortina, M.G., Mora, D., Schumann, P., Parini, C., Manachini, P.L., \& Stackebrandt, E. (2001). Reclassification of Saccharococcus caldoxylosilyticus as Geobacillus caldoxylosilyticus (Ahmad et al. 2000) comb. nov. International Journal of Systematic and Evolutionary Microbiology, 51(Pt 6): 2063-2071.

Hakobyan, L., Gabriely, L., \& Trchounian, A. (2012). Yeast extract as an effective nitrogen source stimulating cell growth and enhancing hydrogen photoproduction by Rhodobacter sphaeroides strains from mineral springs. International Journal of Hydrogen Energy, 37(8): 6519-6526.

Hucker, G. \& Conn, H.J. (1923). Methods of gram staining. New York Agricultural Experiment Station. Technical bulletin 93.

Ibrahim, M.A.C. \& Ahmad, W.A. (2017). Growth optimization of a thermophilic strain Geobacillus caldoxylosilyticus UTM6 isolated from Selayang Hot Spring. eProceedings Chemistry, 2(1): 119123.

Janda, J.M. \& Abbott, S.L. (2007). 16S rRNA gene sequencing for bacterial identification in the diagnostic laboratory: pulses, perils, and pitfalls. Journal of Clinical Microbiology, 45(9): 27612764.

Jeong, J., Yun, K., Mun, S., Chung, W., Choi, S., Nam, Y., Lim, M.Y., Hong, C.P., Park, C., Ahn, Y.J., \& Han, K. (2021). The effect of taxonomic classification by full-length $16 \mathrm{~S}$ rRNA sequencing with a synthetic long-read technology. Scientific Reports, 11: 1727.

Johnson, J.S., Spakowicz, D.J., Hong, B., Petersen, L.M., Demkowicz, P., Chen, L., Leopold, S.R., Hanson, B.M., Agresta, H.O., Gerstein, M., Sodergren, E., \& Weinstock, G.M. (2019). Evaluation of $16 \mathrm{~S}$ rRNA gene sequencing for species and strain-level microbiome analysis. Nature Communications, 10: 5029.

Kalil, M.S., Alshiyab, H.S.S., \& Wan Yusoff, W.M. (2008). Effect of nitrogen source and carbon to nitrogen ratio on hydrogen production using $C$. acetobutylicum. American Journal of Biochemistry and Biotechnology, 4: 393-401.

Kolcuoğlu, Y., Colak, A., Faiz, O., \& Belduz, A.O. (2010). Cloning, expression and characterization of highly thermo- and pH-stable maltogenic amylase from a thermophilic bacterium Geobacillus caldoxylosilyticus TK4. Process Biochemistry, 45(6): 821-828.

Lebre, P., Aliyu, H., De Maayer, P., \& Cowan, D. (2018). In silico characterization of the global Geobacillus and Paragebacillus secretome. Microbial Cell Factories, 17: 156.

Lutkenhaus, L \& Addinall, S.G. (1997). Bacterial cell division and the $\mathrm{Z}$ ring. Annual Review of Biochemistry, 66: 93-116.

Mahon, C.R., Lehman, D.C., \& Manuselis, G. (2018). Textbook of Diagnostic Microbiology. Elsevier Health Sciences. 
Murtey, M.D. \& Ramasamy, P. (2016). Sample preparations for scanning electron microscopy Life Sciences. In Janecek, M. (Ed.), Modern Electron Microscopy in Physical and Life Sciences. InTech, DOI: 10.5772/61720. https://www.intechopen.com/chapters/49652.

Nazina, T.N., Tourova, T.P., Poltaraus, A.B., Novikova, E.V., Grigoryan, A.A., Ivanova, A.E., Lysenko, A.M., Petrunyaka, V.V., Osipov, G.A., Belyaev, S.S. \& Ivanova, M.V. (2001). Taxanomic study of aerobic thermopilic bacilli: descriptions of Geobacillus subterraneus gen. nov., sp. nov. and Geobacillus uzenesis sp. nov. from petroleum reservoirs and transfer of Bacillus stearothermophilus, Bacillus thermocatenulatus, Bacillus thermoleovorans, Bacillus kaustophilus, Bacillus thermodenitrificans to Geobacillus as the new combinations $G$. stearothermophilus, $G$. thermocatenulatus, $G$. thermoleovorans, $G$. kaustophilus, $G$. thermoglucosidasius and $G$. thermodenitrificans. International Journal of Systematic and Evolutionary Microbiology, 51: 433-446.

Obojska, A., Ternan, N.G., Lejczak, B., Kafarski, P., \& McMullan, G. (2002). Organophosphonate utilization by the thermophile Geobacillus caldoxylosilyticus T20. Applied and Environmental Microbiology, 68(4): 2081-2084.

Rahim, A.N.I. \& Ahmad, W.A. 2016. Bioremediation of chromium(vi) to chromium(iii). eProceedings Chemistry. 1(1): 27 30 .
Schoch, C.L., Ciufo, S., Domrachev, M., Hotton, C.L., Kannan, S., Khovanskaya, R., Leipe, D., Mcveigh, R., O’Neill, K., Robbertse, B., Sharma, S., Soussov, V., Sullivan, J.P., Sun, L., Turner, S. \& Karsch-Mizrachi, I. (2020). NCBI taxonomy: a comprehensive update on curation, resources and tools. Database (Oxford), 2020: baaa062.

Seo, M., Lee, B., Pyun, Y. \& Park, H. (2011). Isolation and characterization of $\mathrm{N}$ Acylhomoserine lactonase from the thermophilic bacterium, Geobacillus caldoxylosilyticus YS-8. Bioscience, Biotechnology, and Biochemistry, 75(9): 1789-1795.

Walker, G.M. (1999) Yeast Physiology and Biotechnology. England: John Wiley \& Sons Ltd.

Werner-Washburne, M., Braun, E.L., Crawford, M.E. \& Peck, V.M. (1993). Stationary phase in the yeast Saccharomyces cerevisiae. Microbiological Review, 57: 383-401.

Xiao, J. \& Goley, E.D. (2016). Redefining the roles of the FtsZ-ring in bacterial cytokinesis. Current Opinion in Microbiology, 34: 90-96.

Yunitsyna, O., Sinelnikov, I., Kisil, O., Bolotova, K., Aksenov, A. \& Simonsen, G. (2019). Isolation of thermophilic enzyme-producing Parageobacillus bacteria from chipped woody waste. BioResources, 14(1): 1452-1465.

Zeigler, D.R. (2014). The Geobacillus paradox: why is a thermophilic bacterial genus so prevalent on a mesophilic planet. Microbiology, 160(Pt 1): 111. 